\title{
IN VITRO ASSESSMENT OF BIOACCESSIBILITY OF THE ANTIOXIDANT ACTIVITY OF KOMBUCHA BEVERAGES AFTER GASTRIC AND INTESTINAL DIGESTION ${ }^{\diamond}$
}

\author{
Jasmina S. Vitas*, Ljiljana M. Popović, Jelena C. Čakarević, Radomir V. Malbaša, Stefan Z.
} Vukmanović

University of Novi Sad, Faculty of Technology in Novi Sad, 21000 Novi Sad,

Bulevar cara Lazara 1, Serbia

\author{
*Corresponding author: \\ Phone: +381214853644 \\ Fax: +38121450413 \\ E-mail address: vitasj@uns.ac.rs
}

\begin{abstract}
Kombucha beverage is a fermented product obtained by kombucha culture fermentation of, usually, black or green tea. Besides black and green tea, kombucha also ferments water extracts of medicinal herbs. The obtained products possess antioxidant activity. The aim of this paper was to establish the antioxidant potential of kombucha beverages with black tea, green tea, and medicinal herbs after pepsin and pancreatin in vitro digestion. The radical scavenging ability of DPPH and hydroxyl radical, as well as reducing power of kombucha products was determined. At the end of the digestion process, the highest antioxidant potential towards hydroxyl radical showed only kombucha beverages with peppermint and stinging nettle extract. Results for reducing power and antioxidant capacity to scavenging DPPH radical showed a decrease in values after the digestion process.
\end{abstract}

Key words: kombucha, pepsin, pancreatin, antioxidative potential, herbal drugs

\section{INTRODUCTION}

Bioavailability is the term that refers to the proportion of food that is utilized for reserve and metabolic functions. It includes bioaccessibility and bioactivity. Bioaccessibility is related to processes that take place during digestion and bioactivity to transport and mechanism of action of a bioactive compound (Fernández-García et al., 2009). Investigations of bioavailability are important in order to gain insight into the potential functional property of a certain food product. A modern way of life is oriented to the consumption of food and beverages that can provide nutritional and health beneficial effects for the human organism. Kombucha products are an example of this type of beverages.

Kombucha is a fermented product of natural origin that is consumed worldwide and possesses antioxidant characteristics. This type of product is usually gained through the fermentation of sweetened black or green tea with kombucha culture. Sucrose is usually used as sweetening agent and it represents the source of car-

${ }^{\diamond}$ This paper was reported at the $6^{\text {th }}$ International Conference on Food Digestion held in Granada, Spain in the form of an abstract: Malbaša, R., Vitas, J., Popović, L., Čakarević, J., Vukmanović, S. (2019). Influence of in vitro digestion process on the antioxidant activity of kombucha beverages. $6^{\text {th }}$ International Conference on Food Digestion, Granada, Spain, Proceedings, p. 64. 
bon for kombucha starter, which is consisted of several yeast species (Zygosaccharomyces sp., Torulopsis sp., Saccharomyces bisporus, Saccharomyces cerevisiae and Saccharomycodes ludwigii) and mostly acetic acid bacteria (Acetobacter) (Malbaša et al., 2011). Tea extract containing methylxanthines is used by the starter as the source of nitrogen. The fermentation process usually lasts for 7 days. After this period of time, a beverage that contains numerous nutritive and pharmacologically active compounds is produced. The obtained product is sweet, refreshing, and possesses numerous health benefits stated by the consumers (Jayabalan et al., 2014; Villarreal-Soto et al., 2018).

In order to simulate the mechanism of action of food in physiological conditions in vitro digestion methods were developed (Ketnawa et al., 2019; Ma et al., 2019). In this investigation, in vitro digestion was performed on kombucha fermented beverages with potential functional properties.

Determination of antioxidant activity, as a functional property of different types of consumed products is a characteristic of the ongoing research. For example, fruit beers were analyzed in order to establish antioxidant activity using FRAP and ABTS tests (Nardini and Garaguso, 2020). By free radical scavenging process, oxidative processes are inhibited and, therefore, numerous chronic diseases can be prevented (Ketnawa et al., 2019).

New research is also oriented towards determination of antioxidant potential changes during digestion of crisphead lettuce (Ketnawa et al., 2019), bamboo leaves soup (Ma et al., 2019), as well as Jasonia glutinosa herbal tea (Ortega-Vidal et al., 2019). Determination of antioxidant activity after in vitro gastrointestinal digestion was conducted for cheddar cheese as well (Chen et al., 2019). Ketnawa et al. (2019) suggested that the gastrointestinal tract could perform extraction of antioxidants from food products.

The antioxidant activity of traditional kombucha products with black or green tea is very well established. The examination in- cluded different types of antioxidant tests, such as antioxidant activity to DPPH and hydroxyl radical, scavenging of superoxide anions, antilipid peroxidation (Jayabalan et al., 2008; Malbaša et al., 2011). Antioxidant potential of kombucha with medicinal herbs during fermentation is also evaluated (Vitas et al., 2020).

Research regarding the digestion of kombucha products is scarce, and therefore it is worth investigating how simulated in vitro gastric and intestinal digestion influences the antioxidant potential of these beverages. Abuduaibifu and Tamer (2019) evaluated the bioaccessibility of antioxidant activity of black tea, black and red goji berry kombucha using DPPH, CUPRAC, and FRAP tests. This type of research sets the basis for in vivo investigations. Up to our knowledge, these are the first results regarding in vitro simulated gastrointestinal digestion of kombucha beverages with medicinal herbs and evaluation of the antioxidant potential of products during this process.

The aim of this paper was to establish the bioactive antioxidant ability of alternative kombucha beverages with medicinal herbs after gastric and intestinal digestion.

\section{MATERIALS AND METHODS}

\section{Production of kombucha beverages}

Kombucha beverages were produced according to the procedure described in Vitas et al., 2020. Kombucha culture was cultivated on water extracts of black tea, green tea, winter savory, peppermint, stinging nettle, wild thyme, elderberry and quince. All used herbal drugs were purchased in local health food store. Traditional water extracts for kombucha cultivation (black and green teas) were prepared by adding $70 \mathrm{~g} / \mathrm{L}$ of sucrose and 1.5 $\mathrm{g} / \mathrm{L}$ of tea to boiling tap water. Alternative water extracts for kombucha fermentation (winter savory herb, peppermint leaves, stinging nettle leaves, wild thyme herb, quince leaves) were prepared by adding $70 \mathrm{~g} / \mathrm{L}$ of sucrose and $2.26 \mathrm{~g} / \mathrm{L}$ of the appropriate herbal drug to boiling tap water. Elderberry flowers were added in the amount of $3 \mathrm{~g} / \mathrm{L}$. The obtained water extracts were cooled to room temperature, 
filtered and $10 \%(\mathrm{v} / \mathrm{v})$ of kombucha inoculum from previous fermentation was added. Kombucha cultivation was performed during 7 days, at room temperature. Kombucha beverage with elderberry was produced after 3 days. Samples were marked as presented in Table 1.

Table 1.

Sample marks

\begin{tabular}{ll}
\hline Sample & Mark \\
\hline Kombucha beverage with black tea & BT \\
Kombucha beverage with green tea & GT \\
$\begin{array}{l}\text { Kombucha beverage with winter } \\
\text { savory }\end{array}$ & WS \\
$\begin{array}{l}\text { Kombucha beverage with peppermint } \\
\text { Kombucha beverage with stinging }\end{array}$ & P \\
nettle & SN \\
Kombucha beverage with wild thyme & WT \\
Kombucha beverage with quince & Q \\
Kombucha beverage with elderberry & E \\
\hline
\end{tabular}

\section{In vitro digestion}

In vitro digestion of samples was performed to the method by Čakarević et al. (2019), with some modifications. Digestion was performed in a glass reactor using a combination of two enzymes, pepsin and pancreatin in ratio E/S $1 / 25$, at $37{ }^{\circ} \mathrm{C}$ during $3 \mathrm{~h}$. Sample $(50 \mathrm{~mL})$ was preincubated at $37^{\circ} \mathrm{C}$, then adjusted to $\mathrm{pH} 3$ and added pepsin, gastric phase was performed $60 \mathrm{~min}$. Then, $\mathrm{pH}$ of the solution was adjusted to $\mathrm{pH} 7$ and added pancreatin and intestinal phase was carried out next $120 \mathrm{~min}$. At the end of digestion samples were collected and frozen for further analysis.

\section{Antioxidant activity tests}

Antioxidative potential of obtained kombucha beverages was examined by determination of radical scavenging ability of DPPH and hydroxyl radical, as well as reducing power, after gastric and intestinal digestion.

\section{DPPH radical scavenging ability}

DPPH radical scavenging ability was determined using spectrophotometric method given in Morales and Jiménez-Pérez (2001) with some modifications. Reaction mixture consisted of $1 \mathrm{~mL}$ of sample and
$4.8 \mathrm{~mL}$ standard DPPH solution (80 $\mu \mathrm{mol} / \mathrm{L}$ ethanol (REAHEM, Serbia) solution of DPPH radical (SIGMA-ALDRICH, Germany). Blank sample used $1 \mathrm{~mL}$ of distilled water instead of the sample. Reaction mixtures were kept for 1 hour in dark place at the room temperature and absorbance was measured at $515 \mathrm{~nm}$ using JENWAY 6300 Spectrophotometer, Barloworld Scientific Ltd., UK. DPPH radical scavenging ability (RSA $\left.A_{D P H}\right)$ was expressed as percentages.

\section{Hydroxyl radical scavenging ability}

Hydroxyl radical scavenging ability was performed according to Deeseenthum and Pejovic (2010) with some modifications. The $100 \mu \mathrm{L}$ of sample was mixed with 450 $\mu \mathrm{L}$ of $0.2 \mathrm{~mol} / \mathrm{L}$ sodium phosphate buffer $(\mathrm{pH}=7.00), 150 \mu \mathrm{L}$ of $10 \mathrm{mmol} / \mathrm{L} 2$-deoxyribose (AlfaAesar, Germany), $150 \mu \mathrm{L}$ of 10 $\mathrm{mmol} / \mathrm{L}$ EDTA disodium salt dehydrate (lachner, Czech Republic), $150 \mu \mathrm{L}$ of 10 $\mathrm{mmol} / \mathrm{L} \quad \mathrm{FeSO}_{4} \quad x \quad 7 \mathrm{H}_{2} \mathrm{O} \quad$ (ZDRAVLJE Leskovac, Republic of Serbia), $150 \mu \mathrm{L}$ of $10 \mathrm{mmol} / \mathrm{L} \mathrm{H}_{2} \mathrm{O}_{2}$ (CENTROHEM, Republic of Serbia), and $525 \mu \mathrm{L}$ of distilled water. Reaction mixtures were kept at $37{ }^{\circ} \mathrm{C}$ using Personal Water Bath, BOECO, Germany for $2 \mathrm{~h}$. Afterwards $750 \mu \mathrm{L}$ of $2.8 \%(\% \mathrm{w} / \mathrm{v})$ trichloroacetic acid (J.T. Baker, The Netherlands) and $750 \mu \mathrm{L}$ of $0.1 \% \quad(\% \quad \mathrm{w} / \mathrm{v})$ thiobarbituric acid (AlfaAesar, Germany) was added and the test tubes were kept in boiled water for 10 min. Absorbance was measured at 520 $\mathrm{nm}$ using JENWAY 6300 Spectrophotometer, Barloworld Scientific Ltd., UK. Blank sample used $100 \mu \mathrm{L}$ of distilled water instead of the sample. Hydroxyl radical scavenging ability $\left(\mathrm{RSA}_{\mathrm{OH}}\right)$ was presented as percentages.

\section{Reducing power}

Reducing power was determined according to Yildirim et al., 2001 using modified method. The $300 \mu \mathrm{L}$ of sample was mixed with $2.5 \mathrm{~mL}$ of $0.2 \mathrm{~mol} / \mathrm{L}$ phosphate buffer $(\mathrm{pH}=6.60)$ and $2.5 \mathrm{~mL}$ of $1 \%(\% \mathrm{w} / \mathrm{v})$ potassium ferricyanide (CENTROHEM, Republic of Serbia). Reaction mixtures were kept at $50{ }^{\circ} \mathrm{C}$ using Personal Water Bath (BOECO, Germany) during $30 \mathrm{~min}$. Afterwards, $2.5 \mathrm{~mL}$ of $10 \%$ trichloroacetic 
acid (J.T. Baker, The Netherlands) was added. The $2.5 \mathrm{~mL}$ of this solution was mixed with $2.5 \mathrm{~mL}$ of distilled water and $0.5 \mathrm{~mL}$ of $0.1 \%(\% \mathrm{w} / \mathrm{v}) \mathrm{FeCl}_{3} \times 6 \mathrm{H}_{2} \mathrm{O}$ (SUPERlaboratory, Serbia). Absorbance was measured at $700 \mathrm{~nm}$ using JENWAY 6300 Spectrophotometer, Barloworld Scientific Ltd., UK. Higher absorbance indicates higher reducing power.

\section{Statistical analysis}

All analyses were performed in triplicate. The correlation between antioxidant activity assays after pepsin and pancreatin digestion, were determined by calculating the Pearson's $r$ and $p$-value. With alpha $(\alpha)$ value of $0.05, p \leq 0.05$ was considered statistically significant. Linear regression was performed. Correlation and regression were done using Microsoft Office Excel 2010. One-way ANOVA and Tuckey's test $(p<0.05)$ were performed using Statistica 13.2. (STATISTICA, 2016).

\section{RESULTS AND DISCUSSION}

Kombucha beverage is nowadays consumed around the world and possesses characteristics that relate to a general tonic. It means that kombucha beverage could be used for human consumption in order to treat different health conditions. Kombucha beverages with medicinal herbs such as quince, elderberry, stinging nettle, wild thyme, peppermint, and winter savory can widen the range of offered kombucha products and combine beneficial effects of kombucha and the aforementioned medicinal herbs. The antioxidative potential is one of the beneficial effects that these beverages can provide (Vitas et al., 2020). Gastric and intestinal in vitro digestion was performed in order to obtain conclusions on how these beverages could be used by a human organism. Kombucha products possess beneficial health effects on gastrointestinal functions (Kapp and Sumner, 2019). Literature data suggested that kombucha beverages with black and green tea have the potential to inhibit porcine pancreatic alpha-amylase. This ability was attributed to the phenolic compounds of the beverages. Therefore, traditional kombucha products could affect glucose absorption and starch digestion (Kallel et al., 2012). It is also indicated that the biological properties of kombucha need further studies (Villarreal-Soto et al., 2018). Therefore, antioxidant potential during simulated digestion process was investigated in this study. Antioxidant tests included determination of DPPH and hydroxyl radical scavenging ability, as well as reducing power. Results of the antioxidant potential investigation are given in Figures 1, 2, and 3. Results of radical scavenging ability of DPPH radicals after gastric and intestinal digestion are given in Figure $1 \mathrm{a}$ ) and $\mathrm{b}$ ). Before digestion, the highest RSA $\mathrm{DPPH}_{\mathrm{DP}}$ showed sample $Q(74.70 \%)$ and the lowest sample SN (4.12\%) (Vitas et al., 2020). After pepsin digestion (Figure $1 \mathrm{a}$ )), samples $B T, W T$ and $E$ showed an increase in $\mathrm{RSA}_{\mathrm{DPPH}}$, and all the other samples demonstrated a decrease in this value, in comparison to measurements made before the process. The highest value had sample $E(80.49 \%)$, and the lowest value showed sample SN (1.87\%). Pancreatin digestion (Figure $1 \mathrm{~b}$ )) caused the decrease of RSA $A_{D P P H}$ for all investigated samples, in comparison to values determined before and after pepsin digestion. The highest $\mathrm{RSA}_{\mathrm{DPPH}}$ had sample WT $(25.30 \%)$, and the lowest value was measured for sample SN $(0.10 \%)$. The results of a study on the influence of in vitro digestion process on the antioxidant capacity of bracatinga honeydew honey blends indicated that DPPH radical scavenging ability was higher after the intestinal digestion. This conclusion was attributed to the phenolic compound behavior in an acidic and alkaline environment (Seraglio et al., 2017). On the contrary, the results of this study showed that $\mathrm{RSA}_{\mathrm{DPPH}}$ of all kombucha samples was the lowest at the end of the digestion process, suggesting lower electron or hydrogen donation capacity of kombucha beverages. The results of linear regression analysis indicate a strong positive relationship between $\mathrm{RSA}_{\mathrm{DPPH}}$ after pepsin and pancreatin digestion of kombucha beverages since Pearson's coefficient is 0.74 , and the $p$-value is 0.04 . Used water extract influenced the $\mathrm{RSA}_{\mathrm{DPPH}}$ during gastric and intestinal digestion. After gastric digestion, products with winter savory 


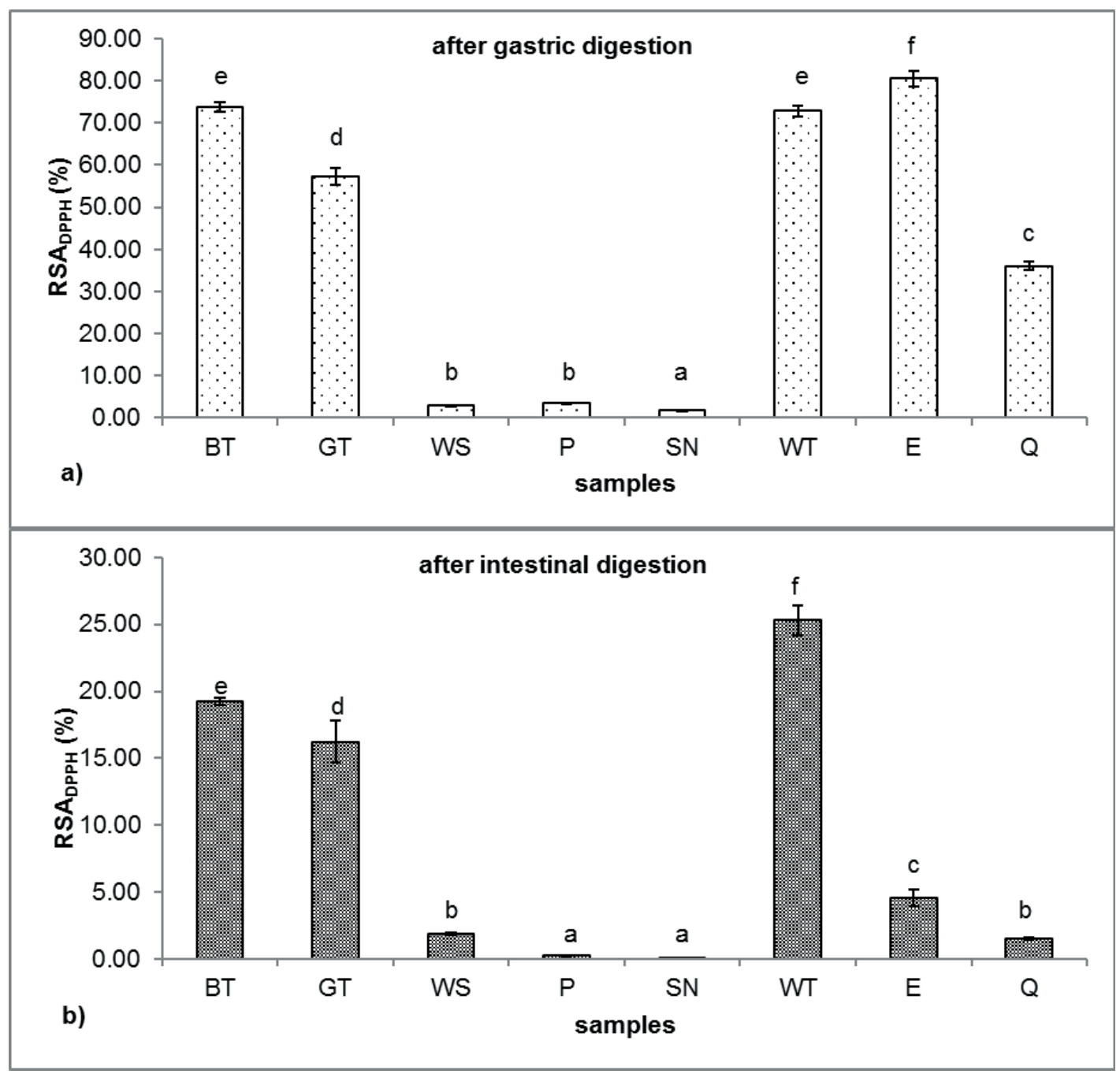

Figure 1. Radical scavenging ability of DPPH radicals $\left(R S A_{D P P H}, \%\right)$ after gastric (a) and intestinal digestion (b) of kombucha beverages

and peppermint, as well as products with black tea and wild thyme, did not differ significantly (Figure 1 a). After intestinal digestion, products with winter savory and quince, as well as beverages with stinging nettle and peppermint showed same level of statistical significance (Figure $1 \mathrm{~b}$ ). Results of hydroxyl radical scavenging ability after gastric and intestinal digestion are given in Figure 2 a) and b). Before the digestion process, the highest $\mathrm{RSA}_{\mathrm{OH}}$ had sample WS (44.37\%), and the lowest value showed sample SN (13.08\%) (Vitas et al., 2020). After gastric digestion (Figure 2 a), RSA ${ }_{O H}$ increased for samples BT, WS, and E, and decreased in the rest of the samples in comparison to values obtained before the process. After pepsin digestion (Figure 2 a), the highest RSA ${ }_{\mathrm{OH}}$ was measured for sample WS $(55.85 \%)$, and the lowest for sample SN (1.24\%). Pancreatin digestion (Figure 2 b)) caused a decrease in RSA ${ }_{\mathrm{OH}}$ for samples $\mathrm{BT}, \mathrm{GT}$, $W S, E$, and $Q$, in comparison to values determined before and after pepsin digestion. Sample WT had the same RSA ${ }_{\mathrm{OH}}$ after pepsin and pancreatin digestion. $\mathrm{RSA}_{\mathrm{OH}}$ increased after pancreatin digestion for samples $\mathrm{P}$ and $\mathrm{SN}$, in comparison to measurements made before and after pepsin digestion. After intestinal digestion, the highest $\mathrm{RSA}_{\mathrm{OH}}$ had sample $P$ $(36.69 \%)$ and the lowest sample $E$ (3.29\%). Hydroxyl radical is the most potent reactive oxygen species. It is short lived and highly reactive. In the human organism, it is mostly produced as the result of the Fenton reaction (Đukić, 2008). 


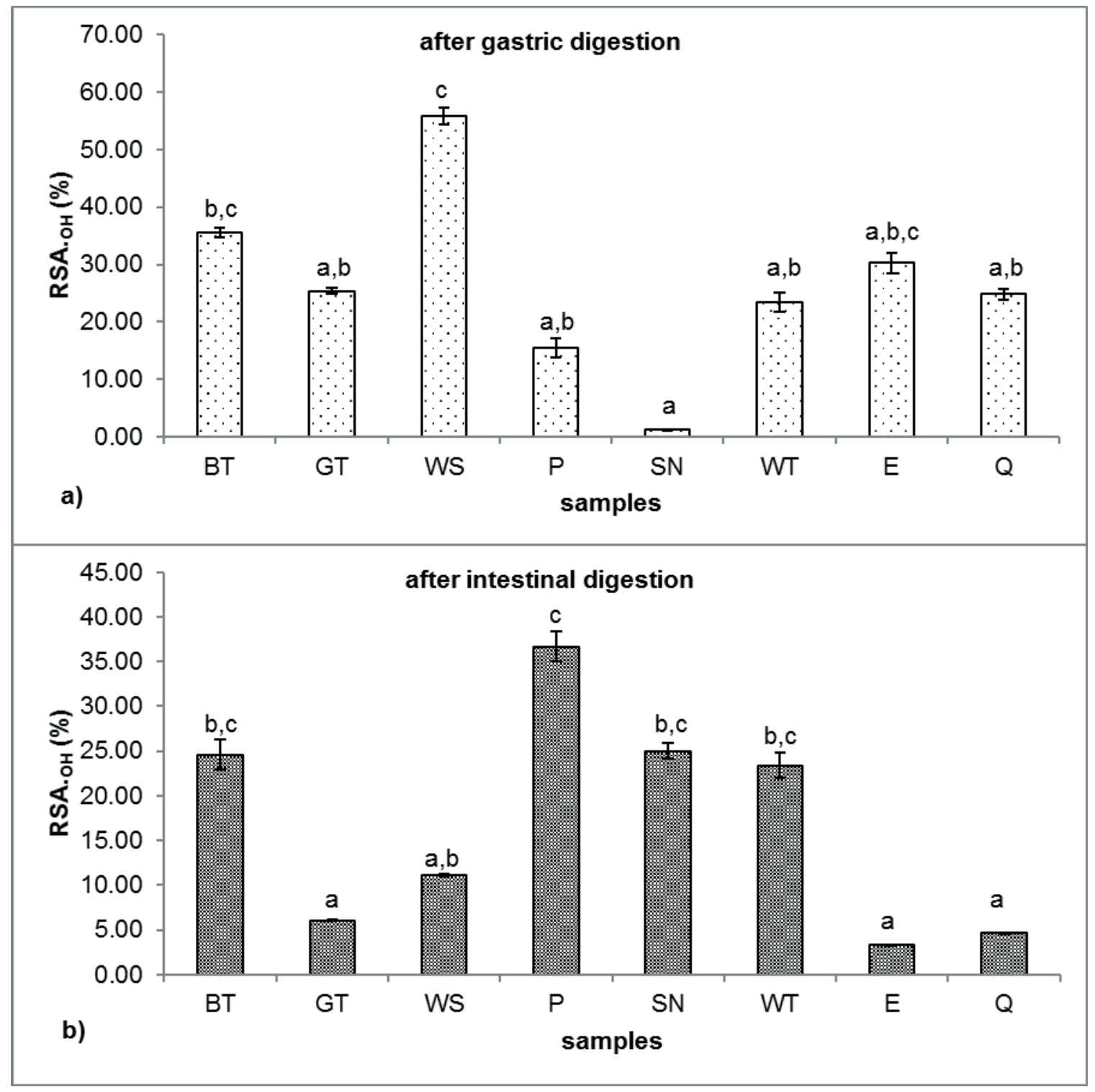

Figure 2. Radical scavenging ability of hydroxyl radicals $\left(\mathrm{RSA}_{\mathrm{OH}}, \%\right)$ after gastric $(\mathrm{a})$ and intestinal digestion (b) of kombucha beverages

Sample WT maintained its $\mathrm{RSA}_{\mathrm{OH}}$ during digestion and samples $P$ and $S N$ showed the highest ability at the end of the process, suggesting that these products could be most effective in scavenging of hydroxyl radical in the human digestive system. The investigation of in vitro gastrointestinal digestion on the antioxidant activity of single and mix of three species of Jarilla genus infusions suggested partial loss of hydroxyl radical scavenging activity after the digestion (Carabajal et al., 2020).

The results of linear regression analysis suggested a moderate negative relationship (Pearson's coefficient $=-0.42$ ) between $\mathrm{RSA}_{\mathrm{OH}}$ after pepsin and pancreatin digestion of kombucha beverages, but it is not statistically significant since the $p$-value is 0.30 . After gastric digestion, a product with winter savory showed the highest value that was significantly different in comparison to other beverages, except when compared to beverages with black tea and elderberry (Figure 2a). After intestinal digestion, a beverage with peppermint showed the highest value that was significantly different in comparison to other beverages, except when compared to products with black tea, stinging nettle, and wild thyme (Figure 2b). Results of reducing power after gastric and intestinal digestion are given in Figure $3 a$ and $3 b$. Before digestion, the highest reducing power had sample SN (0.701), and the lo- 
west value was established for sample BT (0.342) (Vitas et al., 2020). Only sample P showed an increase in reducing power after pepsin digestion in comparison to the measurements made before the process (Figure 3a). The highest reducing power, after gastric digestion, showed sample $\mathrm{SN}$ $(0.588)$ and the lowest value had sample BT (0.155). Intestinal digestion (Figure 3b) caused a decrease in reducing power for samples GT, WS, WT, E, and $Q$, in comparison to the values determined before and after pepsin digestion. The value for samples BT, $\mathrm{P}$, and $\mathrm{SN}$ was higher in comparison to gastric digestion, but lower than before the process. The highest reducing power, after pancreatin digestion, had sample SN (0.637), and the lowest sample BT (0.187). Since all investigated samples demonstrated lower reducing power after the completion of the digestion process, it can be concluded that examined kombucha products are not good sources of protons and electrons. These results are opposite to results obtained after the examination of the effect of in vitro digestion process on the reducing power of traditional Serbian white-brined cheeses. Reducing power of investigated chesses increased after the duodenal pha-

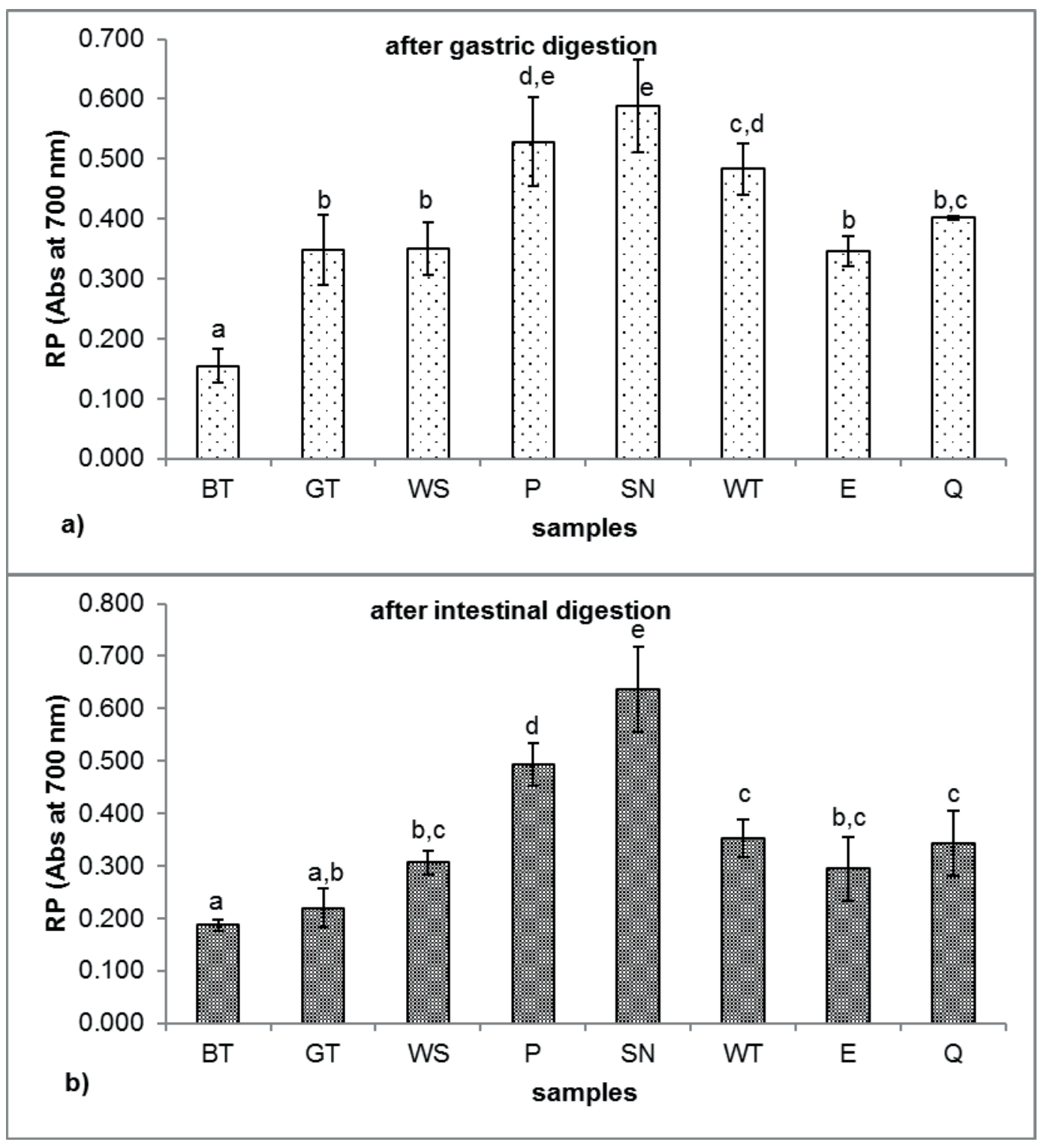

Figure 3. Reducing power (RP, Abs at $700 \mathrm{~nm}$ ) after gastric (a) and intestinal digestion (b) of kombucha beverages 
se (Barac et al., 2019).

The results of linear regression analysis indicated a very strong positive relationship (Pearson's coefficient $=0.90$ ) between RP after pepsin and pancreatin digestion of kombucha beverages, with $p$ value $=0.003$. After gastric digestion, the product with stinging nettle showed the highest value that was significantly different in comparison to other beverages, except when compared to a beverage with peppermint (Figure 3a). After intestinal digestion, a beverage with stinging nettle showed the highest value that was significantly different in comparison to other beverages (Figure $3 \mathrm{~b}$ ). Alternative water extracts used for kombucha fermentation were more suitable regarding the reducing power values since a product with black tea had significantly lower values after the digestion process in comparison to beverages that contained medicinal herbs ( $\mathrm{Fi}-$ gure $3 a$ and $b$ ).

\section{CONCLUSIONS}

Alternative kombucha beverages with medicinal herbs, as well as traditional kombucha products, were successfully evaluated in terms of antioxidant potential after gastric and intestinal in vitro digestion.

In comparison to values obtained before digestion and after pancreatin treatment, beverages with black tea, wild thyme, and elderberry had the highest DPPH radical scavenging ability after pepsin digestion. This difference was most pronounced for the product with elderberry.

The radical scavenging ability of DPPH and reducing power was the lowest after pancreatin digestion for all samples.

Beverages containing black tea, winter savory, and elderberry showed the highest hydroxyl radical scavenging ability after pepsin digestion, in comparison to values obtained after pancreatin digestion and before the process. Products with peppermint and stinging nettle had the highest hydroxyl radical scavenging ability at the end of the digestion process. Only sample with peppermint had the highest reducing power value after pepsin digestion.
Only sample with peppermint had the highest reducing power value after pepsin digestion.

Based on the obtained results, kombucha beverages with peppermint and stinging nettle should be further studied since their antioxidant potential towards hydroxyl radical, i.e. the radical that can be generated in human organism, increased as a result of the digestion process.

In order to gain a detailed insight into the determination of antioxidant potential of kombucha beverages during in vitro digestion process, studies that include chemical composition determination are necessary, as well. Analyses of vitamins, enzymes, and phenolic compounds that possess the antioxidant characteristics are a part of future experiments.

Besides, additional antioxidant testing will give more insight into antioxidant ability of kombucha beverages with herbal teas.

\section{ACKNOWLEDGEMENTS}

This research was financially supported by the Ministry of Education, Science and Technological Development, Republic of Serbia (Grant 451-03-68/2020-14/200134) and the Provincial Secretariat for Higher Education and Scientific Research (Project name: Kombucha beverages production using alternative substrates from the territory of the Autonomous Province of Vojvodina; Project No. 142-451-2400/201903).

\section{REFERENCES}

1. Abuduaibifu, A., Tamer, C.E. (2019). Evaluation of physicochemical and bioaccessibility properties of goji berry kombucha. Journal of Food Processing and Preservation, 43 (9), 1-14.

2. Barac, M., Vucic, T., Zilic, S., Pesic, M., Sokovic, M., Petrovic, J., Kostic, A., Sredovic Ignjatovic, I., Milincic, D. (2019). The effect of in vitro digestion on antioxidant, ACE-inhibitory and antimicrobial potentials of traditional Serbian white-brined cheeses. Foods, 8 (3), 94.

3. Carabajal, M.P.A., Isla, M.I., Borsarelli, C.D., Zampini, I.C. (2020). Influence of in vitro gastroduodenal digestion on the antioxidant activity of single and mixed three "Jarilla" species infusions. Journal of Herbal Medicine, 19, 100296.

4. Chen, P, Liu, L., Zhang, X., Bora, A.F.M., Li, X. Zhao, M., Hao, X., Wang, Y. (2019). Antioxidant 
activity of Cheddar cheese during its ripening time and after simulated gastrointestinal digestion as affected by probiotic bacteria. International Journal of Food Properties, 22 (1), 217228.

5. Čakarević, J., Vidović, S., Vladić, J., Gavarić, A., Jokić, S., Pavlović, N., Blažić, M., Popović, L. (2019). Production of bio-functional protein through revalorization of apricot kernel cake, Foods, 8 (318), 1-12.

6. Deeseenthum, S., Pejovic, J. (2010). Bacterial inhibition and antioxidant activity of kefir produced from Thai jasmine rice milk. Biotechnology, 9 (3), 332-337.

7. Đukić, M. (2008). Reaktivne hemijske vrste i oksidativni stress. In Oksidativni stres - slobodni radikali, prooksidansi $i$ antioksidansi. Ed. Mirjana M. Đukić, MONO I MANJANA, Beograd, 3-23. (in Serbian).

8. Fernández-García, E., Carvajal-Lérida, I., Pérez-Gálvez, A. (2009). In vitro bioaccessibility assessment as a prediction tool of nutritional efficiency. Nutrition Research, 29 (11), 751760 .

9. Jayabalan, R., Subathradevi, P., Marimuthu, S., Sathishkumar, M., Swaminathan, K. (2008). Changes in free-radical scavenging ability of kombucha tea during fermentation. Food Chemistry, 109 (1), 227-234.

10. Jayabalan, R., Malbaša, R.V., Lončar, E.S., Vitas, J.S., Sathishkumar, M. (2014). A review on Kombucha tea-microbiology, composition, fermentation, beneficial effects, toxicity, and tea fungus. Comprehensive Reviews in Food Science and Food Safety, 13 (4), 538-550.

11. Kallel, L., Desseaux, V., Hamdi, M., Stocker, P., Ajandouz, El H. (2012). Insights into the fermentation biochemistry of Kombucha teas and potential impacts of Kombucha drinking on starch digestion. Food Research International, 49 (1), 226-232.

12. Kapp, J. M., Sumner, W. (2019). Kombucha: a systematic review of the empirical evidence of human health benefit. Annals of Epidemiology, 30, 66-70.

13. Ketnawa, S., Suwannachot, J., Ogawa, Y. (2019). In vitro gastrointestinal digestion of crisphead lettuce: Changes in bioactive compounds and antioxidant potential. Food Chemistry, 311, 125885, https://doi.org/10.1016/i.foodchem.2019.125885.

14. Ma, Y., Yang, Y., Gao, J., Feng, J., Shang, Y.,
Wei, Z. (2019). Phenolics and antioxidant activity of bamboo leaves soup as affected by in vitro digestion. Food and Chemical Toxicology, 135, 110941, https://doi.org/10.1016/j.fct.2019.110941.

15. Malbaša, R., Lončar, E., Vitas, J., Čanadanović-Brunet, J. (2011). Influence of starter cultures on the antioxidant activity of kombucha beverage. Food Chemistry, 127 (4), 1727-1731.

16. Morales, F.J., Jiménez-Pérez, S. (2001). Free radical scavenging capacity of Maillard reaction products as related to colour and fluorescence. Food Chemistry, 72 (1), 119-125.

17. Nardini, M., Garaguso, I. (2020). Characterization of bioactive compounds and antioxidant activity of fruit beers. Food Chemistry, 305, 125437 , https://doi.org/10.1016/j.foodchem.2019.125437.

18. Ortega-Vidal, J., Ruiz-Riaguas, A., Fernándezde Córdova, M.L., Ortega-Barrales, P., LlorentMartínez, E.J. (2019). Phenolic profile and antioxidant activity of Jasonia glutinosa herbal tea. Influence of simulated gastrointestinal in vitro digestion. Food Chemistry, 287, 258-264.

19. Seraglio, S.K.T., Valese, A.C., Daguer, H., Bergamo, G., Azevedo, M.S., Nehring, P., Gonzaga, L.V., Fett, R., Costa, A.C.O. (2017). Effect of in vitro gastrointestinal digestion on the bioaccessibility of phenolic compounds, minerals, and antioxidant capacity of Mimosa scabrella Bentham honeydew honeys. Food Research International, 99, 670-678.

20. STATISTICA (Data Analysis Software System) (2016). v.13.2, Stat-Soft, Inc., USA (www.statsoft.com).

21. Villarreal-Soto, S.A., Beaufort, S., Bouajila, J., Souchard, J.P., Taillandier, P. (2018). Understanding Kombucha tea fermentation: A review. Journal of Food Science, 83 (3), 580-588.

22. Vitas, J., Vukmanović, S., Čakarević, J., Popović, Lj., Malbaša, R. (2020). Kombucha fermentation of six medicinal herbs: chemical profile and biological activity. Chemical Industry \& Chemical Engineering Quarterly, OnLineFirst, https://doi.org/10.2298/C/CEQ190708034V.

23. Yildirim, A., Mavi, A., Kara, A.A. (2001). Determination of antioxidant and antimicrobial activities of Rumex crispus L. extracts. Journal of Agricultural and Food Chemistry, 49 (8), 40834089. 


\title{
IN VITRO ПРОЦЕНА БИОЛОШКЕ ДОСТУПНОСТИ АНТИОКСИДАТИВНЕ АКТИВНОСТИ КОМБУХА НАПИТАКА НАКОН ГАСТРО И ИНТЕСТИНАЛНЕ ДИГЕСТИЈЕ
}

\author{
Јасмина С. Витас*, Љиљана М. Поповић, Јелена Ц. Чакаревић, Радомир В. Малбаша, \\ Стефран 3. Вукмановић \\ Универзитет у Новом Саду, Технолошки фракултет Нови Сад, \\ 21000 Нови Сад, Булевар цара Лазара бр. 1, Србија
}

Сажетак: Комбуха напитак је ферментисани производ добијен фрерментацијом културе комбухе на, уобичајено, црном или зеленом чају. Сем црног и зеленог чаја, комбуха такође ферментише водене екстракте медицинских биљака. Добијени производи поседују антиоксидативну активност. Циљ овог рада је било утврђивање антиоксидативног потенцијала комбуха напитака са црним чајем, зеленим чајем и биљним дрогама након in vitro дигестије пепсином и панкреатином. Одређени су способност стабилизације и трансформације DPPH и хидрокси радикала, као и редукциона моћ комбуха производа. Комбуха напици са наном и копривом су показали највећу способност хватања хидрокси радикала на крају процеса дигестије. Резултати добијени за редукциону моћ и антиоксидативну активност на DPPH радикал су показали да након процеса дигестије долази до пада ових вредности.

Кључне речи: комбуха, пепсин, панкреатин, антиоксидативни потенцијал, биљне дроге

Received: 13 January 2020

Received in revised form: 6 May 2020

Accepted: 30 May 2020 